\title{
CRIMINAL ALTERNATIVE MEASURES IN RELATION TO DEPRIVATION OF LIBERTY MEASURES IN SLOVAK REPUBLIC COMPARED TO SPAIN, ITALY, PORTUGAL AND AUSTRIA ${ }^{1}$
}

\section{TRESTNOPRÁVNE ALTERNATÍVNE OPATRENIA VO VZŤAHU K OPATRENIAM POZBAVUJÚCIM OSOBNÚ SLOBODU V SLOVENSKEJ REPUBLIKE V POROVNANÍ SO ŠPANIELSKOM, TALIANSKOM, PORTUGALSKOM A RAKÚSKOM}

\author{
Lukáš Michal'ov ${ }^{2}$ \\ https://doi.org/10.33542/SIC2020-2-05
}

\begin{abstract}
In this article, the author deals with alternative criminal measures, possibilities of their imposition and execution in the Slovak Republic in comparison with selected European countries, namely Spain, Italy, Portugal and Austria. By alternative measures the author understands not only alternative sentences, but also alternatives to deprivation of liberty in pre-trial proceedings and alternatives to imprisonment during its execution. The purpose of this article is to analyze chosen alternative measures in selected countries, to compare them with the Slovak national legislation and to look for inspiration for potential changes in the Slovak national legislation.
\end{abstract}

\begin{abstract}
ABSTRAKT
Autor sa v tomto článku zaoberá trestnoprávnymi alternatívnymi opatreniami, možnostami ich ukladania a výkonu $v$ Slovenskej republike v porovnaní s vybranými štátmi Európy, a to Španielskom, Talianskom, Portugalskom a Rakúskom. Alternativnymi opatreniami autor chápe nielen alternativne tresty, ale aj alternativy $k$ pozbaveniu osobnej slobody $v$ predsúdnom konani a alternatívy knepodmienečného trestu počas jeho výkonu. Účelom tohto článku je analyzovat' jednotlivé alternativne opatrenia vo vybraných štátoch, tieto komparovat' so slovenskou vnútroštátnou úpravou ahladat' takto inšpiráciu aj pre potenciálne zmeny slovenskej vnútroštátnej právnej úpravy.
\end{abstract}

\section{INTRODUCTION}

The issue of alternative measures is a reflection of the so-called concepts of restorative sentencing and justice. A key aspect of the concept of restorative sentencing, respectively the concept of restorative justice is an effort to find an alternative solution to criminal cases, not

\footnotetext{
This scientific paper came with support and is the output of a research project of the Agency for the Support of Research and Development in Slovak Republic in the framework of the project: Privatization of Criminal Law - substantive, procedural, criminological and organizational - technical aspects; no. APVV-16-0362; Tento príspevok vznikol s podporou a je výstupom riešenia výskumného projektu Agentúry na podporu výskumu a vývoja v rámci projektu: Privatizácia trestného práva - hmotnoprávne, procesnoprávne, kriminologické a organizačno-technické aspekty; č. APVV-16-0362.

2 JUDr., PhD., Univerzita Pavla Jozefa Šafárika v Košiciach, Právnická fakulta, Slovenská republika University of Pavol Jozef Šafárik in Košice, Faculty of Law, Slovak Republic.
} 
only in the area of substantive criminal law, but also in the area of criminal procedural law. The system of restorative sentencing represents a way of treating offenders different from the classical concept of retributive sentencing, or retributive justice (so-called punitive justice). Retributive justice is generally associated with the notion of sentence, the imposition of which on the offender is a basic access to solve the crime. On the other hand, restorative justice is generally considered to be a process in which several parties are involved as a result of the crime committed by offender and harm caused to the victim. ${ }^{3}$ Restorative justice is built on the idea of the existence of criminal justice, in which elements emphasizing the rights of victims and the extrajudicial hearing of criminal cases are represented. This relatively new concept in our conditions considers the crime primarily as harming one person by another. Restorative justice is therefore often referred to as restoring justice.

Alternative measures in criminal law have recently had an irreplaceable place. Modern legal systems of European countries already reflect the need to implement alternative measures, because these measures can reduce the negative effects of imprisonment on the offender and reduce negative economic effects on the country and at the same time the protection of society is secured.

In this article, we will focus on the legislation of these alternatives in selected European countries that are also members of the European Union, namely Spain, Portugal, Italy and Austria and we will briefly compare it with the Slovak legislation.

In terms of the structure of the article, we will focus our attention on the following types of alternatives:

1. Pre-trial alternatives, understood as alternatives to deprivation of liberty before the conviction of the offender,

2. Alternative sentences (sanctions) understood as alternatives to unconditional imprisonment,

3. Alternatives during the execution of imprisonment understood as alternatives that can be used during the execution of imprisonment to shorten the duration of imprisonment.

\section{What led European countries to implement alternative measures}

There are several reasons that have led modern European countries to implement alternative measures. The search for new forms of sentencing and new forms of justice is inextricably linked with the development of society. ${ }^{4}$ Countries have realized that unconditional imprisonment does not always correct the offender. In addition, the offender is able to absorb criminal influences in the prison facility that have an impact on his future criminal career. Other reasons are of an economic nature, which are related to the cost of imprisonment and the gradual overcrowding of the prisons, which can currently be seen as a Europe-wide problem. However, reasons can also be found in strengthening the rights of the victim and victims position in the criminal proceedings, where an alternative measure can significantly help to eliminate the side effects of the crime and restore it to its original state, of course in the case of less serious crimes. Other reasons that cannot be overlooked are historical, social or geopolitical ones, including migration, especially in the countries of southern Europe where criminality has increased and it consequently affects prison capacities and causes prison overcrowding. ${ }^{5}$

KLÁTIK, J. a kol. Trestné právo hmotné. Všeobecná čast'. Plzeň : Vydavatelství a nakladatelství Aleš Čeněk, 2018. ISBN 9788073807252.

4 ALBRECHT, H. Sanction Policies and alternative measures to incarceration: European experiences with intermediate and alternative criminal penalties. Available on web:

https://www.unafei.or.jp/publications/pdf/RS_No80/No80_07VE_Albrecht.pdf.

5 JUNGER-TAS, J. Alternatives to prison sentences. Experiences and developments. Studies on crime and justice, a series from the Dutch research and documentation centre.1994. ISBN 90-6299-111-4. Available on web: https://english.wodc.n1/binaries/ov-1994-01-full-text_tcm29-77924.pdf. 
All selected European countries are aware of the need for a probation service to exist and be strengthened, because the probation service is necessarily related to alternative measures. It is the probation service that ensures the control and effective execution of alternative measures and it is necessary to provide it with sufficient personnel, material and technical support. $^{6}$

\section{Slovak Republic}

The Slovak Republic is a relative novice in the field of alternative measures, especially in relation to the alternative sentences. New forms of justice have been enshrined in the Criminal Code since 2006, but their use and actual implementation have encountered many legal or organizational-technical obstacles and problems that have caused that these alternative measures have not been imposed. A relative novelty in the Slovak Republic is the introduction of electronic monitoring by Act no. 78/2015 Coll. on the control of the enforcement of certain decisions by technical means, which has extended the possibilities for imposing alternative measures and the effectiveness of their enforcement. ${ }^{7}$

Pre-trial alternatives

Pre-trial alternatives in the Slovak Republic include so-called reasons for the replacement of custody $^{8}$ (bond, detention), among which we recognize the replacement of custody by a guarantee of a trustworthy person or an interest association of citizens, a written promise of the accused, replacement under the supervision of a probation and mediation officer, or a financial guarantee (bail, deposit).

When replacing custody, the judge may impose one or more appropriate restrictions or obligations, in particular

- a ban on traveling abroad,

- a prohibition on carrying out an activity in which a criminal offense has been committed,

- a ban on visits to designated places,

- the obligation to hand over a legally held weapon,

- a ban on moving away from the place of residence or residence itself, except under defined conditions,

- the obligation to appear regularly or at a specified time at a state body designated by the court,

- a ban on driving a motor vehicle and the handing over a driving license,

- a ban on contact with certain persons or a prohibition on intentionally approaching a person at a distance of less than five meters,

- the obligation to deposit funds for the purpose of securing the injured party's claim for damages,

- prohibition or restriction of contact with the designated person in any form, including contact by electronic communications service or any other similar means; or

6 FERENČÍKOVÁ, S. Možnosti aplikácie inštitútu probácie pri výkone detencie. In: Aplikácia nových prístupov k človeku v kontexte mediačnej a probačnej práce : zborník príspevkov z medzinárodnej vedeckej konferencie Dni probácie a mediácie. Prešov : Prešovská univerzita v Prešove, 2017. - ISBN 9788055518206.

7 See, for example:

KLIMEK, L. Execution of Electronic Monitoring in Slovak Criminal Justice. In Academic International Conference on Interdisciplinary Legal Studies, Vol. 10. Oxford Conference Series. Livingston: FLE Learning, 2019, ISBN 978-1911185- 90-1, pp. 22-29. KLIMEK, L. Costs of Electronic Monitoring in Slovak Criminal Justice. In Academic International Conference on Social Sciences and Education. Cambridge Conference Series. Vancouver: FLE Learning, 2019, ISBN 978- 1-913016-23-4, pp. 8- 13. KLIMEK, L. - KLÁTIK, J. Electronic Monitoring in Slovak Criminal Justice. In HÁJEK, P. - VÍT, O. Innovations in Science and Education. CBU International Conference Proceedings 2019. Prague: CBU Research Institute, 2019, ISBN 978- 80-907722-0-5, pp. 459-463.

8 Provisions of $\S 80$ et seq. of the Slovak Criminal Procedural Code. 
- a prohibition on staying in the vicinity of the designated person's residence or in the designated place where such person is staying or visiting. ${ }^{9}$

Custody in the conditions of the Slovak Republic is not understood as a sentence, but as a measure used to ensure the presence of the accused for the purposes of criminal proceedings. We recognize three basic types of custody, namely flee, collusion (influencing) and prevention custody. We also recognize anti-terrorism custody and others.

\section{Alternative sentences}

Alternative sentences that compete with unconditional imprisonment include Home prison (detention), Compulsory work, Financial sentence (fine), The ban of participation in public events, Conditional suspension of imprisonment, Conditional suspension of imprisonment with the probation supervision and Expulsion.

Home prison ${ }^{10}$ (detention), its front-end type, can currently be imposed for crimes with a maximum imprisonment of up to ten years. This sentence has undergone several legislative changes. The purpose of this sentence is that the offender will serve the entire sentence in a chosen dwelling while using electronic monitoring. The offender is not excluded from everyday life, he can work, shop and move at the time determined by the court, which undoubtedly affects the subsequent reintegration of the offender into everyday life after serving this sentence, because social, family or work ties and relationships have not been broken ${ }^{11}$.

Compulsory work ${ }^{12}$ is another typical alternative sentence for less serious crimes. It is interesting that it can be imposed only with the consent of the offender, because not every country, using this sentence, requires the consent of the offender for its imposing. Compulsory work can be imposed in an extent of forty to three hundred hours. The offender is obliged to perform the sentence of compulsory work personally, in his free time without the right to be paid.

Financial sentence ${ }^{13}$ (fine) is another necessary alternative in the system of alternative sentences, especially in the case of property and economic crimes or crimes where imposition of financial sentence is necessary for society protection and punishing the offender.

The ban on participation in public event ${ }^{14}$ is the latest alternative sentence and its purpose is to eliminate the offender's access to events in which his participation is from a criminological point of view, the cause of the crime. It is especially effective in relation to sport events for non-adaptable fans.

Conditional suspension ${ }^{15}$ of imprisonment and conditional suspension of imprisonment with probation supervision are other alternatives for less serious crimes. The purpose of these alternatives is that imprisonment is imposed by a court to offender, but it is suspended on a probationary period of up to five years. If the offender leads a proper life during the probationary period, he does not have to serve imprisonment.

Expulsion $^{16}$ is also considered by some authors as an alternative sentence, the purpose of which is to exclude a person (offender) from the country in which he commits crime and prohibit his entry into the territory of the country if the crime is related to the need to protect the country and public order.

\footnotetext{
Provisions of $\S 82$ of the Slovak Criminal Procedural Code.

10 Provision of $\S 53$ of Slovak Criminal Code.

11 TÓTHOVÁ, V., FERENČIKOVÁ, S. Innovation in criminal policy of imposing alternative sanctions in Slovak Republic. In: CBU International Conference Proceedings 2019: Innovations in Science and Education: March 20-22, 2019, Prague, Czech Republic. - Praha: CBU Research Institute, 2019. - ISBN 9788090772212.

12 Provisions of $\S 54$ and 55 of Slovak Criminal Code.

13 Provisions of $\S 56$ and 57 of Slovak Criminal Code.

14 Provision of $\$ 62$ a of Slovak Criminal Code; Effective from 2014.

15 Provisions of $\S 49$ et seq. of the Slovak Criminal Code.

16 Provision of $\S 65$ of Slovak Criminal Code.
} 


\section{Alternatives during execution}

Conditional release from imprisonment (Parole) is an important institute for offenders who have shown during the execution in prison that they can behave properly, have shown that they have learned from their failure, regret their crime and will be able to lead a proper life. Legislation dealing with conditional release from imprisonment always depends on criminal policy of the country and is related to realistic conditions for the execution of imprisonment, for example prison overcrowding. It is a very popular and requested institute. In the Slovak Republic offender can be released after half, two thirds, or three quarters of the imprisonment imposed. It depends on the seriousness of the crime. Offenders sentenced for life imprisonment may be released on parole at the earliest after serving twenty five years of imprisonment.

The back-end type or Conversion of the remainder of imprisonment into a home prison (detention) is a relatively new institute that allows the offender to serve the last part of the imprisonment in a home prison (detention). So far, this institute is not very popular, because offenders significantly prefer parole.

\section{Spain}

Regarding to increasing a prison population in Spain, politicians pointed out the need to continue providing more importance to development of alternatives to short sentences of imprisonment. It all started in 2000. The implementation of alternatives measures was, along with others, one of the government strategies to reduce or control prison numbers.

\section{Alternative sentences}

We can recognize two main alternative sentences in Spanish legislation, Suspension and Substitution of imprisonment.

Suspension $^{17}$ of imprisonment is possible for sentences up to two years. It is used for example for first time offenders with the possibility of the fulfilment of other obligations. It is also available for offenders with serious illness or with incurable disease, when it is not necessary to fulfil requirements. If the offender committed a crime because of his dependence on drugs for imprisonment up to five years, it can be imposed only with combination of detoxification programs.

Substitution ${ }^{18}$ of imprisonment is a real alternative, where imprisonment is substituted by one of alternatives, or combination of alternatives. Imprisonment can be substituted by Fine for sentences up to one year, by Community service for sentences up to one year. One day of imprisonment equals one day of work. The offender is obliged to render assistance unpaid in certain activities of public interest, which may include to repair on the damage caused or to support victims as well as participation in workshops or education training or retraining, labor, cultural, traffic, sexual and so on. Permanent location is another alternative for sentences of imprisonment up to six months. One day of imprisonment equals on day of permanent location. The last one is Expulsion for foreigners, combined with prohibition to come back to Spain.

In the case of Suspension and Substitution of imprisonment the court may also impose obligations and duties, for example:

- Prohibition to visit a certain place,

- Prohibition to approach the victim, or his relatives or other persons determined by the court or to communicate with them,

- Prohibition to leave the residence without authorization by a court,

- Personal appearance in court or police station,

17 Provisions of $\S 80-87$ of Spanish Criminal code.

18 Provisions of $\S 88$ and 89 Spanish Criminal code. 
- Participation in training, labor, employment, cultural programs, driver and traffic education, sexual and environmental defense training program, animal protection program or similar activities,

- Other duties imposed by court for resocialization with the offender's approval, as long as these are not contrary to offender personal dignity.

Alternatives during execution

Very interesting is possibility to substitute imprisonment during its execution by Expulsion $^{19}$ for foreigners and imprisonment up to six years. Imprisonment can be substituted by expulsion or prohibition to come back in five to ten years. It is necessary that offender has served already three quarters of the sentence. Foreigner may not be allowed to return to Spain within ten years from the date of his expulsion in any case. Slovak legislation does not use expulsion as an alternative during execution of imprisonment.

Parole (Conditional release from imprisonment) is very important institute. General requirement is that offender has served three quarters of sentence and has favorable prognosis of social reintegration. There are also exceptional circumstances to encourage collaboration in the treatment (overtaking possibility of release upon completion of two thirds or half of the sentence, in consideration of the merits contracted by participating in continuous and profitably own activities). And special circumstances provided for cases of elderly or sick offenders, where is possible temporary release without prior compliance requirement on humanitarian grounds, difficulty and little danger crime, those punishable by seventy or more years old, as well as seriously ill with incurable diseases. ${ }^{20}$

Electronic monitoring is also considered as alternative, which allows a specific form of sentences serving in open regime, replacing mandatory minimum time staying at the establishment by electronic means or other suitable control systems. The prison administration currently has the following electronic surveillance:

- By bracelets monitoring system for telephone service or via switched network (fixed) or via mobile, through the so-called cell units,

- Voice verification systems, both through fixed telephones on the control sites, or through devices that transmit information using cell lines,

- Continuous monitoring systems internally by GPS technologies that allow the Administration to know the geographical location of the subject at all times, and it establishes areas of mandatory stay or unauthorized access (areas of inclusion or exclusion),

- Mobile monitoring units to control inmates with telematic bracelets in different usual locations (for example the workplace),

- Combined systems of location with telematic systems bracelets with alcohol control remotely.

\section{Portugal}

One of the reasons for considering alternative measures in Portugal was big mortality in Portuguese prison facilities. They wanted to reduce prison population and make imprisonment more effective by thinking of alternatives. With the financial crisis of 2008-2009 the prison overcrowding alarm sounded again. An ambitious mega-prison building program ran out of funding. The government attempted to remedy the problem of overcrowding by stuffing more beds into existing facilities. Yet the problem continued to grow with prison population

9 Provision of $\S 89$ of Spanish Criminal Code.

20 OCANA M., Alternatives to prison is Europe Spain. European Prison Observatory. Alternatives to detention. 2015, ISBN 978-88-98688-18-0. Available on web: http://www.prisonobservatory.org/alternatives/ ALTERNATIVES\%20TO $\% 20$ PRISON \%20\%20EUROPE.\%20SPAIN.pdf. 
reaching $120 \%$ of the capacity. Using electronic monitoring is nowadays important in Portugal. Electronic monitoring was subject of many public debates and various studies. It was first legislated in 1999 and codified in 2001. After a trial period (2002-2004) involving pre-trial detainees, it became an option for the application of other existing alternative measures by the courts. Its application may be, in practical terms, the most significant alternative measure in the Portuguese system. ${ }^{21}$

Pre-trial alternatives

We found out that Portugal has many options of pre-trial alternatives. First, Term of identity and residence is an alternative to pre-trial detention. This measure may be imposed by the police authority once the individual has been charged. This measure consists of requirement of presentation to authorities and to inform of any change of address for more than five days.

Bail is an alternative to pre-trial detention and consists of paying an amount set by the court. If the offender cannot to afford pay bail, the court may substitute bail for any other measure. The amount of bail depends on the type of the crime, damages that may have occurred and the socioeconomic situation of the offender.

Mandatory periodic presentation is another alternative to pre-trial detention. It can be applied in cases with potential sentences of more than six months of imprisonment. The offender is obliged to present himself periodically (the period determined by the court) at some official location, such as a police station, or a courthouse. It is very similar to probationary supervision in the Slovak legislation.

Suspension of work, function, activities or rights can be applied to crimes with a maximum sentence to two years of imprisonment. The offender may be ordered to suspend any professional activity or any other occupation, parental rights, rights to manage property or any other rights according to the crime.

Prohibition and imposition of activities as another alternative can be applied to crimes with a maximum imprisonment to three years. Access to some areas, possessing items such as weapons, or contacting with certain individuals can be prohibited.

Conditional Suspended case is an alternative to pre-trial detention. The case may be suspended upon request of the accused to the Prosecutor's Office or by the prosecutor's own initiative. The case may be suspended for up to two years. If the accused complies with all suspension, duties and obligations throughout the duration of the suspension, the case is then dismissed.

House arrest (home prison, or detention in pre-trial proceedings) is another alternative to pre-trial detention. The individual may not leave the place of residence (private residence, treatment center or health care facility) in prescribed time without prior authorization. Offender can be authorized to work. Usually electronic monitoring is being used.

Alternative sentences

Some alternative sentences in Portugal are very similar to Slovak alternatives. Some are the total novelty and inconceivable in Slovak legislation.

Community service ${ }^{22}$ is a typical alternative sanction, which can be applied as substitution for imprisonment of up to two years and requires the consent of the individual as in the Slovak Republic. This sanction consists of unremunerated services for the state, other collective public entities or private entities whose aims may be considered as the public interest. Each day of the imprisonment corresponds to one hour of work, to a maximum of

\footnotetext{
21 DORES, A., PONTES, N., LOUREIRO, R. Alternatives to prison Europe Portugal. European Prison Observatory. Alternatives to detention. 2015, ISBN 978-88-98688-20-3. Available on web: http://www.prisonobservatory.org/alternatives/ALTERNATIVES\%20TO\%20PRISON\%20IN\%20EUROPE.\%20PORTU GAL.pdf.

22 Provision of $\S 58$ of Portuguese Criminal Code.
} 
four hundred and eighty hours. The work can be performed on weekdays, weekends or holidays. If the offender is employed, the community service cannot interfere with the performance of employment.

Suspended sentence of imprisonment ${ }^{23}$ is an alternative sanction which can be used as alternative to maximum three years of imprisonment. The court considers personality of sentenced, circumstances and behavior of the sentenced and so on. The court also imposes the suspension period, which is fixed between one and five years counting from the time the sentence had become definite.

Substitution of imprisonment sentence is an alternative sanction for sentences not higher than one year. Imprisonment can be substituted for a fine or for another sentence, with the exception of cases where imprisonment is necessary to prevent future crimes. If the individual fails to pay the fine, imprisonment must then be served.

Home prison (detention) is an alternative sanction based on electronic monitoring and with the consent of the offender, what we find very interesting comparing to the Slovak legislation. The court may impose this alternative for sentences up to a maximum of one year (or up to two years, if the subject is younger than twenty one or older than sixty five, has a serious disease or disability, is in charge of minors or has someone dependent for care).

Imprisonment by free days ${ }^{24}$ is a partially alternative sanction for sentences up to a maximum of one year. The court may permit the sentence to be served on the weekend. Semi imprisonment regime ${ }^{25}$ is a partially alternative sanction for sentences of up to one year. The court may permit the sentence to be served in prison but with permission to leave daily to work or to attend school. This alternative requires the consent of the individual. Imprisonment by free days is impossible in the Slovak legislation. Semi imprisonment regime is very similar to execution of imprisonment in an open section in a prison facility with a minimum degree of guarding in the Slovak Republic.

\section{Alternatives during execution of sentence}

Parole (Conditional release from imprisonment) is included in the work of the Probation Department. It consists of the earlier release, upon completion of a prescribed minimum, always with the consent of the individual.

Sentence modification for need is not a typical alternative. This measure permits the exceptional release of sick offenders.

\section{Italy}

Between 2000 and 2005, Italy has ratified three Acts having a great impact on the increasing of prison population, the Act on immigration (2002), the Act on drugs (2006) and the Act on strengthening punishments and making the access to alternatives to imprisonment more difficult or even impossible for recidivists (2005). As the only reaction to prison overcrowding, in 2006 the Parliament ratified a pardon, after prison population restarted unavoidably growing. In January 2010, the Government declared a state of emergency in relation to the penitentiary system. It started to take measures aiming at decreasing the number of prisoners, first of all with the possibility of serving the last part of the sentence at home. In January 2013 the European court of Human rights convicted Italy for violation of art. 3 in relation to prison overcrowding. It was a pilot-judgment, which imposed Italy to solve the systemic problem of overcrowding within one year. Italy reacted with new acts by strengthening alternative measures and reducing of sentenced for good behavior. These normative changes have contributed to the decrease of prison population. ${ }^{26}$

\footnotetext{
Provisions of $\S 50$ - 57 of Portuguese Criminal Code.

Provision of $\S 45$ of Portuguese Criminal Code.

Provision of $\S 46$ of Portuguese Criminal Code.

26 MARIETTI, S. Alternatives to prison Europe Italy. European Prison Observatory. Alternatives to detention. 2015, ISBN
} 


\section{Pre-trial alternatives}

Italy legislation has many pre-trial alternatives comparing to the other examined countries. Home detention (prison) is ordered by judge, when offender is not authorized to leave his home or another private house. Usually electronic monitoring is used. The judge can prohibit or limit the communication between the offender and people not living with him. If the offender has no other means of support, the judge can permit him to leave the established place for the minimum time necessary to provide his needs or to work.

Then we recognize Prohibition to leave the Country, which is ordered by judge, when the offender is not allowed to leave the country without permission. Other is the Requirement to report all the information about work activities and residence to police on a periodic basis. Prohibition to visit the home is used when the offender is obliged to leave the house where his family lives, if adding prohibitions to frequency places that are often visited by some members of the family are needed and the obligation of economically contributing to the family life. Prohibition to visit places visited by the victim is special prohibition to visit places frequented by victim or persons having some kind of emotional relationship with the victim. Prohibition or obligation to live in some specified places is used when it is necessary to keep or keep out the offender in a specified place. Then we recognize other pre-trial alternatives in Italy as, Suspension of parental rights, Suspension from a public office or service, Temporary interdiction from performing professional activities.

„Messa alla prova,, as pre-trial alternative can be used in case of crimes punishable with no more than four years of imprisonment, when the offender has the possibility of requiring the suspension of the criminal proceeding. If the suspension is conceded, the person is put on probation under the control of the social services and with a program to be followed. The program involves actions directed to the restoration of the damage caused by the offence. The suspension of the criminal proceeding on probation cannot be conceded more than once. The positive ending of the probation extinguishes the crime. ${ }^{27}$

Alternative sanctions

Financial sanction (Fine) is an alternative to imprisonment. There are two kinds of financial sanctions called „multa“ and ,ammenda“ depending on the seriousness of the crime. The 'multa' consists of the payment to the State of an amount between $50 €$ to $50.000 €$. The 'ammenda' consists of the payment to the State of an amount of money between $20 €$ and $10.000 €$.

Semi-imprisonment is an alternative which can be used for the imprisonment lower than six months. Offenders are is obliged to spend at least ten hours per day in special prison sections. One day of imprisonment equals to one day of semi-imprisonment. The number of hours and the location depends on working or educational needs of the sentenced. Semiimprisonment involves also other duties and obligations. If these are not respected by the sentenced, semi-imprisonment is converted into imprisonment.

Supervised liberty. Sentence to three months of imprisonment or lower can be substituted with the prohibition to leave the Municipality in which the offender lives (except in case of authorization granted time by time for working, educational, familiar or health reasons). One day of imprisonment equals to two days of supervised liberty. Supervised liberty involves also other duties and obligations, for example to go at least once a day to the law enforcement station, the driver license suspension, the passport withdrawal and so on. The surveillance

978-88-98688-21-0. Available on web: http://www.prisonobservatory.org/alternatives/ALTERNATIVES\%20TO \%20PRISON \%20IN\%20EUROPE.\%20ITALY.pdf.

27 MARIETTI, S. Alternatives to prison Europe Italy. European Prison Observatory. Alternatives to detention. 2015, ISBN 978-88-98688-21-0. Available on web: http://www.prisonobservatory.org/alternatives/ ALTERNATIVES\%20TO\%20 PRISON\% 20IN\%20EUROPE.\%20ITALY.pdf. 
judge can involve the social services in interventions directed to the social reintegration of the offender.

Expulsion of the irregular foreigner. Imprisonment imposes for unintentional crimes considered to be lower than two years of imprisonment can be substituted with the offender's expulsion from Italy in case of irregular foreigners.

Community service is an alternative sanction, which consists in unpaid work in favor of the community, public authorities or private organizations. Community service requests the offender's consent what is common in examined countries.

Alternatives during execution of sentence

The Italian penitentiary law provides more alternatives during execution of imprisonment, which include Involvement in social service programs (being free and having a program to be followed), semi-liberty (being free during part of the day and spending the night in prison) and home detention (serving the sentence at home). It also provides the possibility of working outside prison. Finally, it provides the possibility of spending some days at home and the possibility of having a reduction of imprisonment of forty five days (raised to seventy five days during the years of the emergency related to prison overcrowding) for semester if the sentenced respects prison rules. Then Italian penitentiary law provides Community service, Expulsion of the foreign prisoners and Parole - Conditional release from imprisonment as alternatives during execution of imprisonment.

\section{Austria}

In Austria, government also recognized the need to seek new forms of justice, from probation and mediation to other alternative measures. ${ }^{28}$ In this regard, we dare to say that Austria had a great inspiration in Germany.

\section{Pre-trial alternatives}

Detention in Austria can be replaced by institutes which are also regulated in procedural rules, as well as by others. As a "milder substitute for detention" is used:

- a promise that the accused will not flee or hide until the termination of the criminal proceedings, nor will he leave his place of residence without the permission of prosecutor,

- a promise that the accused will not try to obstruct or complain about investigation,

- in the case of domestic violence, a promise to refrain from any contact with the victim, not to enter a particular apartment and its immediate surroundings, or not to violate the entry ban, including the removal of all keys from the apartment,

- the order to live in a certain place, with a certain family, to avoid certain flats, certain places or certain contacts, to avoid alcoholic beverages or other addictive substances or to get engaged in organized work,

- an order to report any change of residence or to report to the police or another place at certain intervals,

- temporary withdrawal of passports, motor vehicle documents or other authorizations,

- preliminary social guardianship,

- provision of security,

- an order with the consent of the accused to undergo addiction treatment, medical care, psychotherapy, or a medical measure. ${ }^{29}$

These alternatives are very similar to the Slovak legislation.

28 STRÉMY, T., KLÁTIK, J. Alternatívne tresty. Bratislava : C.H. Beck, 2018, ISBN 978-80-89603-56-5.

29 BUCEKOVÁ, M. Podmienky rozhodovania o väzbe v Rakúsku. In. Magister Officiorum 3/2012. Available on web: http://www.ucps.sk/PODMIENKY_ROZHODOVANIA_O_VAZBE_V_RAKUSKU. 
Austrian criminal procedural law also recognizes the so-called domestic detention, which is carried out in the place of residence in which the accused has established his residence. The accused is not taken out of his social environment, lives in orderly living conditions and agrees to his observation through appropriate means of electronic surveillance. Leaving the place of residence is not permitted, with the exception of going to the place of employment or preparation for employment, in order to obtain the necessary things for life and to receive the necessary medical assistance.

\section{Alternative sentences}

Home prison in Austria is not regulated as a typical alternative to imprisonment as in the Slovak Republic, but applies as a specific form of serving imprisonment, but it also can be replaced by the pre-trial detention as described above. Since 2010, electronically monitored home prison has been enshrined in Austrian law. Depending on this, electronically monitored home prison can replace the execution of imprisonment in full (front-end type) or only after the execution of part of the sentence (back-end type). The Austrian legislation thus makes the serving of a sentence in the form of a home prison on the offender's activity, since he must express an interest in the home prison imposing and express his consent by requesting such a form of imprisonment.

Compulsory work or community service used to be served as an alternative sentence first for juvenile offenders. Only later, since 2000, it has been possible to impose this sentence on adult offenders. It cannot be imposed as a separate sentence as in the Slovak Republic, only as an alternative to imprisonment with a maximum of two hundred forty hours, a maximum of eight hours per day and forty hours per week. ${ }^{30}$

Financial penalty (fine) is other alternative, the difference from the Slovak Republic is that it is imposed in the form of daily fines.

\section{Alternatives during execution of sentence}

In principle, these alternatives identified as same as in several states, namely Conditional release from imprisonment (Parole) with similar conditions as in other states, namely the execution of a certain part of the sentence and decent behavior without a prognosis of recidivism) and Back-end type of home prison.

\section{Comparative evaluation}

By comparing the legal systems of the examined European countries in the field of alternative measures, we found that these are indeed in many ways similar, partly harmonized, nevertheless we still find a number of differences and inspirations for changes in Slovak legislation.

Differences can be justified by several factors. There is no doubt that geopolitical and historical aspects in particular need to be taken into account.

It is also necessary to take into account that not all alternatives are alternatives in our Slovak understanding. These alternatives are various exceptions, respectively institutes that are flexible but not pure alternative measures compared to our Slovak national legislation.

Pre-trial alternative measures in Portugal, Italy, but also Austria are a great inspiration for Slovak criminal law. For example, home detention (custody) is nothing new and exceptional in the examined countries or in other countries. However, the Slovak criminal law regulation does not recognize home detention (custody), what we consider as a huge negative. Many offenders prosecuted for a crime do not belong to the prison environment and living in a prison environment can have destructive effects on their mental health and psyche and can

30 RIDERSTALLER, J. Alternatives to custody for young offenders. International juvenile justice observatory. Available on web: http://www.oijj.org/sites/default/files/baaf_austria1.pdf. 
affect their future lives. And especially in cases where the offender is not facing an unconditional sentence of imprisonment.

Otherwise, other alternative measures in pre-trial proceedings are very similar to the reasons for replacing detention (custody) under the Slovak Criminal Procedural Code.

In relation to alternative sentences, practically every examined legislation knows the conditional suspension of the execution of imprisonment, compulsory work, a fine, or home prison. These are typical alternative sentences of modern European legal systems. What would be an absolute novelty in the conditions of the Slovak Republic is Imprisonment by free days in Portugal, when the offender is serving imprisonment on weekends. What is also worth mentioning is the Semi imprisonment regime in Portugal or Italy, which has similar features to the execution of imprisonment in an open section of a prison facility with a minimum degree of guarding. These alternatives are inspiring, but unthinkable in the current conditions of the Slovak Republic. Greater flexibility in the prison system and special prison facilities would be needed if we want to think about these alternatives. These are all alternative institutes that can be used to inspire and significantly improve the national Slovak legislation, which appears to be slightly rigorous and conservative in comparison with the examined countries.

Common alternative measures during the execution of imprisonment include, in particular, parole and back-end type of home prison (detention). Even in relation to these measures, the Slovak Republic can seek inspiration in the legal systems of the examined countries.

As for the comparison among individual states, perhaps the biggest intersections can be seen between the Slovak Republic and Austria, which is certainly caused by the geopolitical situation, economic orientation, legal principles, common borders and history within one country. For example, Spain has the largest intersections in the examined area with Portugal, but also with Italy.

\section{CONCLUSION}

Legislation according to alternative measures is currently necessary in modern criminal law. European countries are struggling with many existential problems in the area of criminal law, and effective regulation and implementation of alternative measures is one of the solutions.

The Slovak Republic is a newcomer to alternative measures but is working to improve alternative institutes. However, we are convinced that more can be done in the area of alternative measures.

That is why the purpose of this article was to map and analyze the issue of alternative measures in other European countries such as Spain, Italy, Portugal and Austria, as these countries have better developed legislation in many areas.

In functioning systems, it is possible to look for inspiration and knowledge, and it is also necessary to think about potential legislative changes in the Slovak Republic, especially in the area of alternatives to detention (custody) in criminal proceedings, or more effective execution of alternative sentences for less serious crimes. We believe that the academic public can also contribute to these issues by summarizing alternative institutes in European countries.

\section{KEY WORDS}

alternative measures, alternative sentences, imprisonment, parole, selected European countries

\section{KLUUČOVÉ SLOVÁ}

alternatívne opatrenia, alternatívne tresty, trest odňatia slobody, podmienečné prepustenie, vybrané štáty Európy 


\section{BIBLIOGRAPHY}

1. ALBRECHT, H. Sanction Policies and alternative measures to incarceration: European experiences with intermediate and alternative criminal penalties. Available on web: https://www.unafei.or.jp/publications/pdf/RS_No80/No80_07VE_Albrecht.pdf.

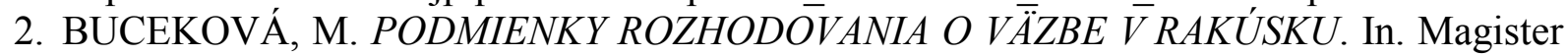
Officiorum 3/2012. Available on web: http://www.ucps.sk/PODMIENKY_ROZHODOVANIA_O_VAZBE_V_RAKUSKU.

3. DORES, A., PONTES, N., LOUREIRO, R. Alternatives to prison Europe Portugal. European Prison Observatory. Alternatives to detention. 2015, ISBN 978-88-98688-20-3. Available on web: http://www.prisonobservatory.org/alternatives/ALTERNATIVES\%20TO\%20PRISON\%2 0IN\%20EUROPE.\%20PORTUGAL.pdf.

4. FERENČÍKOVÁ, S. Možnosti aplikácie inštitútu probácie pri výkone detencie. In: Aplikácia nových prístupov $\mathrm{k}$ človeku $\mathrm{v}$ kontexte mediačnej a probačnej práce : zborník príspevkov z medzinárodnej vedeckej konferencie Dni probácie a mediácie. - Prešov : Prešovská univerzita v Prešove, 2017. - ISBN 9788055518206.

5. HOCHMAYR, G. Elektronisch überwachter Hausarrest, Zur Regelung in Deutschland und Österreich. In Zeitschrift für Internationale Strafrechtsdogmatik [www.zisonline.com]. 2012, roč. 6, č. 11 [cit. 2016-02-28] Dostupné na internete: http://www.zisonline.com/dat/artikel/2012_11_712.pdf.

6. JUNGER-TAS, J. Alternatives to prison sentences. Experiences and developments. Studies on crime and justice, a series from the Dutch research and documentation centre.1994. ISBN 90-6299-111-4. Available on web: https://english.wodc.nl/binaries/ov-1994-01-fulltext tcm29-77924.pdf.

7. KLĀTIK, J. a kol. Trestné právo hmotné. Všeobecná čast'. Plzeň : Vydavatelství a nakladatelství Aleš Čeněk, 2018. - ISBN 9788073807252.

8. KURUCOVÁ, V. Úspech trestu domáceho väzenia v okolitých krajinách - návod pre nás?. In Zahraniční vlivy na vnitrostátní právo. Praha: Leges, 2014. ISBN 978-80-7502- 017-8, s. 121-129.

9. MARIETTI, S. Alternatives to prison Europe Italy. European Prison Observatory. Alternatives to detention. 2015, ISBN 978-88-98688-21-0. Available on web:

http://www.prisonobservatory.org/alternatives/ALTERNATIVES\%20TO\%20PRISON\%2 0IN\%20EUROPE.\%20ITALY.pdf.

10. OCANA M., Alternatives to prison is Europe Spain. European Prison Observatory. Alternatives to detention. 2015, ISBN 978-88-98688-18-0. Available on web: http://www.prisonobservatory.org/alternatives/ALTERNATIVES\%20TO\%20PRISON\%2 0IN\%20EUROPE.\%20SPAIN.pdf.

11. PADFIELD, N, van ZYL SMIT, D., DUNKEL, F. Release from Prison. European policy and practice. 2010. Routlege. Available on web:

https://books.google.sk/books?id=RABSrEEQtoUC\&pg=PA198\&dq=conditional+release + from + prison $\& \mathrm{hl}=\mathrm{cs} \& \mathrm{sa}=\mathrm{X} \& \mathrm{ved}=0 \mathrm{ahUKEwj} 8 \mathrm{mvWV}$ _PoAhW6RhUIHcaYDLEQ6AEI

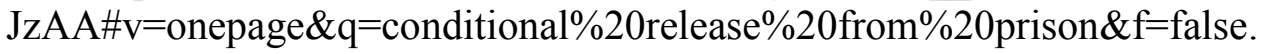

12. RIDERSTALLER, J. Alternatives to custody for young offenders. International juvenile justice observatory. Available on web: http://www.oijj.org/sites/default/files/baaf_austria1.pdf.

13. ROMŽA, S. Alternatívne spôsoby výkoñu trestov. - Košice : Univerzita Pavla Jozefa Šafárika v Košiciach, 2018. - ISBN 9788081526534. 
14. STRÉMY, T., KLÁTIK, J. Alternatívne tresty. Bratislava : C.H. Beck, 2018, 288s, ISBN 978-80-89603-56-5.

15. TÓTHOVÁ, V., FERENČIKOVÁ, S. Innovation in criminal policy of imposing alternative sanctions in Slovak Republic. In: CBU International Conference Proceedings 2019: Innovations in Science and Education : March 20-22, 2019, Prague, Czech Republic.- Praha : CBU Research Institute, 2019. - ISBN 9788090772212.

16. Criminal Code of the Kingdom of Spain. Available on web: https://www.legislationline.org/download/id/6443/file/Spain_CC_am2013_en.pdf.

17. Criminal Code of Portugal. Available on web: https://www.legislationline.org/download/id/4288/file/Portugal_CC_2006_en.pdf.

18. Criminal Code of Slovak Republic.

19. Criminal procedural Code of Slovak Republic.

\section{CONTACT DETAILS OF THE AUTHOR}

JUDr. Lukáš Michal'ov, PhD.

Assistant Professor

Pavol Jozef Šafárik University in Košice

Faculty of Law, Department of Criminal Law

Kováčska 26, 04075 Košice

E-mail: lukas.michalov@upjs.sk

Tel.: + 421552344148 